\title{
NORMAL STRESSES AT THE TIRE-SOIL INTERFACE IN YIELDING SOILS
}

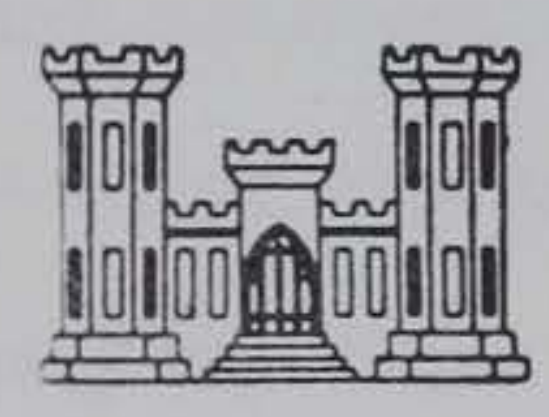

MISCELLANEOUS PAPER NO. 4-629

February 1964

U. S. Army Engineer Waterways Experiment Station CORPS OF ENGINEERS

Vicksburg, Mississippi

ARMY-MRC VICKSBURG, MISS. 
This paper presents the results of a study conducted to determine the magnitude and distribution of the normal stresses at the tire-soil interface, and was presented at the Annual Meeting of the Highway Research Board in Washington, D. C., 13-17 January 1964.

The study was conducted at the U. S. Army Engineer Waterways Experiment Station under the sponsorship and guidance of the Directorate of Research and Development, U. S. Army Materiel Command, as part of Department of the Army Project 1-T-0-21701-A-046, "Trafficability and Mobility Research," Task 1-T-0-21701-A-046-03, "Mobility Fundamentals and Model Studies."

The tests were made by personnel of the Army Mobility Research Branch, Mobility and Environmental Division, under the supervision of Mr. W. J. Turnbull, Technical Assistant for Soils and Environmental Engineering; Mr. W. G. Shockley, Chief of the Mobility and Environmental Division; Mr. S. J. Knight, Chief of the Army Mobility Research Branch; and Mr. D. R. Freitag, Chief of the Mobility Section. Mr. A. J. Green had the primary responsibility for conducting the tests. The paper was written by Messrs. Freitag, Green, and N. R. Murphy, Jr.

Directors of the Waterways Experiment Station during the course of the investigations and the preparation of this paper were Col. E. H. Lang, CE, and Col. Alex G. Sutton, Jr., CE. Technical Director was Mr. J. B. Tiffany. 
NORMAL STRESSES AT THE TIRE-SOIL INTERFACE IN YIELDING SOILS by D. R. Freitag, A. J. Green, N. R. Murphy, Jr.* Introduction

The U. S. Army Engineer Waterways Experiment Station at Vicksburg, Mississippi, is conducting systematic studies that will provide information on factors which influence vehicle mobility in deformable soils. The ultimate purpose of these studies is to develop rational means of designing military vehicles that will provide specified levels of performance in off-road conditions.

A study of the stresses at the interface of a moving pneumatic tire and the medium upon which it travels is one such study. A pilot study to determine the distribution of stresses under pneumatic tires on an unyielding surface was conducted in the fall of 1961, and the results were

* Chief, Engineer, and Mathematician, respectively, Mobility Section, Mobility and Environmental Division, U. S. Army Engineer Waterways Experiment Station, $\mathrm{CE}$, Vicksburg, Miss. 
presented at the 4lst Annual Meeting of the Highway Research Board.* Following this study, an extensive program was initiated to investigate and evaluate the factors that influence magnitude and distribution of the normal stresses between a pneumatic tire and deformable soils. While the objective of these studies is primarily military, the results will be applicable in many other fields. For instance, the development of knowledge pertaining to the stresses and strains or deformation at the tire-soil interface is important to the agricultural researcher who tries to minimize the compaction effect of pneumatic tires, and to the construction engineer who in many instances must depend upon the kneading action of pneumatic tires to help compact a fill or subgrade material.

This paper describes the results of tests made to measure the distribution of stresses at the tire-soil interface under some representative test conditions. Two soils, a sand and a clay, carefully placed in a test pit, were used in the program. Each soil was tested at three different levels of strength. Only one tire at one test load was employed, but stresses were measured at several different inflation pressures. Tests were conducted with the wheel powered and with it towed.

\section{Test Soils}

\section{Description}

The sand used was a medium-to-fine sand, subangular in shape, poorly graded, and classified as SP according to the Unified Soil Classification

* D. R. Freitag and A. J. Green, "Distribution of stresses on an unyielding surface beneath pneumatic tires," Stress Distribution in Earth Masses, Highway Research Board Bulletin No. 342 (Washington, D. C., 1962), pp 14-23. 
System (USCS). The clay, taken from an alluvial deposit in the Vicksburg, Mississippi, area was classified as CH under the USCS. The gradation and classification data for both soils are shown in Figure 1.

Preparation

Sand. The sand was placed in an open pit that had been lined with a waterproof membrane. This pit was approximately 4-1/2 ft wide, $100 \mathrm{ft}$ long, and $3-1 / 2 \mathrm{ft}$ deep.

After the pit was filled and subsequently after each test, the sand was loosened by tilling and then recompacted in place prior to the next test. Tilling was done with a simple multitooth scarifier that was pulled back and forth through the section until the sand was adequately loosened. The maximum depth of tillage possible with this equipment was 36 in. The actual depth of tillage and the amount of compaction necessary varied, depending upon the soil strength desired and upon the strength that had resulted from previous traffic on the section. The equipment used for tilling and compacting (scarifier and vibrator) was attached to the test carriage (described later) and towed at a uniform rate of speed (about $1.0 \mathrm{fps})$. The goal of the soil processing work was to obtain a test section in which the strength increased uniformly with depth and was consistent along the length of the test lane.

Cone index measurements were made to evaluate the effectiveness of the processing for each test. Cone index, an index of soil strength, is the force per unit area required to push a 30 -deg right circular cone into the soil at a rate of 72 in. per min.*

* U. S. Army Engineer Waterways Experiment Station, CE, Trafficability of Soils, A Summary of Trafficability Studies Through 1955, Technical Memorandum 3-240, 14th Supplement (Vicksburg, Miss., December. 1956). 
Clay. A stockpile of natural clay was turned and worked until it had been air-dried to about 8 percent moisture content. The clay was then fed through a conveyor system that metered the soil into the hopper of a disintegrator. Here the lumps of soil were broken into smaller sizes and dropped into a roller crusher. The crusher broke the clods down to a maximum diameter of $1 / 8 \mathrm{in}$. and fed them into a pug mill. A preselected quantity of water was metered into the pug mill and blended into the soil to provide uniform texture and the desired water content. The prepared soil issued continuously from the end of the pug mill and dropped into a truck. It was then transported to the test pit. The soil was dumped into the test pit in sufficient quantity to produce layers approximately 6 in. thick. Each layer was tilled with a pulvimixer and compacted by a pneumatic-tired roller. The compacted 6-in. layer was scarified to a depth of approximately $1-1 / 2$ in. before the next soil layer was placed. The surface of each layer was moistened during construction to compensate for the loss in moisture due to evaporation. This procedure was continued until the top of the section was 1 to 2 in. above the desired grade. The excess material was then sliced off by a section of grader blade mounted on the test carriage, and the soil was allowed to "cure" for one or more days to ensure a uniform moisture content throughout the section. In this case the goals of the soil processing were to obtain a strength profile that showed little or no increase in strength with depth, and to achieve a degree of saturation of 95 percent or greater in order to minimize the effects of traffic on soil strength.

Cone index measurements and moisture-density determinations were made to determine the effectiveness of the processing procedures. When a group 
of tests was conducted at a single soil strength, the fine-grained soil was reprocessed in place. This was done by backfilling the rut left by previous traffic, compacting the surface with pneumatic-tired and smooth-drum rollers, and then leveling the section. It was found that by sprinkling the surface of the section frequently and keeping it covered between actual test runs, the original strength of the material could be maintained for periods up to 60 days.

\section{Test Apparatus}

\section{Test carriage}

Tests were conducted with a single-wheel test carriage that can accommodate wheels up to $56 \mathrm{in.}$ in diameter and $26 \mathrm{in.} \mathrm{in} \mathrm{width.} \mathrm{The} \mathrm{car-}$ riage controls the path and alignment of the test wheel and is designed to isolate and measure the resultant horizontal and vertical forces and the torque at the wheel. Devices for determining degrees of tire rotation, forward travel of the carriage, and vertical movement of the hub of the test wheel are part of the system. Figure 2 is an overall view of this test carriage.

Instrumented tire

Tire. An 11.00-20, 12-ply rating, military tire from which all tread had been removed by buffing was used in this program. In buffing the tire, only the thickness of the lugs was removed so that the thickness and shape of the tire carcass were very nearly those of the original. Deflection gages were mounted inside the tire to determine changes in cross-sectional shape in the tire contact area. Stress cells, mounted in the tire so that their diaphragms were flush with the tire's outer surface, were used to 
measure normal stresses at the tire-soil interface during the operation.

Stress cells. Seven stress cells, $0.75 \mathrm{in}$. in diameter and $0.25 \mathrm{in}$. in height, were mounted in the face of the tire. On the basis of the type of construction (deflecting diaphragm) and the calibration procedures used, these cells are considered to measure stresses normal to their diaphragms. A protective steel cup around the cell prevents the tire from exerting pressure on the cell's sidewall, as such a pressure would cause the diaphragm to deflect and thus invalidate the pressure cell measurements. The walls and bottom of the cup are $1 / 16$ in. thick, and the inside radius of the cup is $1 / 32$ in. larger than that of the cell. A semiconductor strain gage constitutes the pressure-sensitive element of each cell, and resistors are used to complete a full wheatstone bridge circuit. Figure 3 illustrates graphically the electrical circuit from the pressure cell to the recorder. The use of semiconductors permits the construction of a more durable gage, because they are much more sensitive than ordinary foil strain gages.

Seven holes, each large enough to accommodate a cell and cup as described in the preceding paragraph, were cut in the outer surface of the tire, and slits were cut leading from the holes to accommodate the conductor wires of each cell. The seven cells were installed along a diagonal line across the face of the tire (see Figure 4) to avoid serious weakening of the tire in the single cross-sectional plane. The total depth of the cell and cup was approximately equal to the thickness of the rubber over the outermost layer of cord, and for this reason extreme care had to be taken when cutting the tire to avoid damage to the cords. The bottom of the cup was bonded to the tire with a latex-base adhesive. The area 
between the outer walls of the cup and the tire was backfilled with a pliable rubber-base compound that did not adhere to the tire or the cup. The cell was fastened to the cup with a thin layer of bituminous adhesive so that the cell would stay in place during traffic, but could be easily removed for calibration or repair. A strip of thin rubber membrane was used to cover the entire cell area to prevent damage to the diaphragm of the cell and to prevent sand from getting in the area between the cup and the wall of the cell. The membrane was fastened to the tire with a thin plastic adhesive tape that could deform as the tire carcass did without providing additional strength to the tire carcass.

Deflection gages. Commercially available linear and circular potentiometers were used to measure deflections inside the tire. A linear and a circular potentiometer were combined to make one gage and inserted through a port in the rim and tube as shown in Figure 5. A pointed brass tip attached to the end of the potentiometer shaft was held firmly against a point inside the tire by a spring. Movements of this point in line with the potentiometer shaft and in an arc around the center of rotation of the circular potentiometer were recorded. Five gages were employed, each positioned to record movements at a different point on the left-hand side of the tire. Since it was not physically possible to place more than one gage in the same cross section, they were placed in separate cross sections normal to the plane of rotation of the tire. The gages were rotated to the desired angular position while outside the tire, and the circuit that included the circular potentiometer was balanced at that position. The gage was then placed in the port, and the base was tightened in position. After this had been done, the positioning strings (see Figure 6) were used to 
rotate the gage until the circular potentiometer circuit for that gage was rebalanced, indicating that the gage was in the desired position.

\section{Test Conditions}

Both towed- and powered-wheel tests have been conducted in sand, but to date only towed tests have been conducted in clay. Various combinations of load, inflation pressure, and soil strength were studied in the towed tests; during the powered-wheel tests, slip also was a controlled variable.

\section{Methods Used in Analysis of Test Results}

\section{Data reduction}

In the form in which they are first obtained, the data are merely simultaneous records of the measurements. At each instant of time, data are recorded that describe the angular position of a stress cell relative to the wheel axle, the position of the cell or the deflected tire, the vertical movement of the wheel axle, and the registration of the stress cell. All these data must be considered simultaneously to arrive at the proper value of a stress at a given point on the tire-soil interface.

In the reduction of the test data for this study, the shape of the deflected tire cross section was determined at 5-deg intervals of rotation. The positions of the stress cells were then located on each cross section. From these plots the circumferential position for each cell was determined. Each of the cell registrations, which represent the stress variation over the length of the tire contact area at a particular distance from the center line of the tire, was then properly oriented relative to the deflected tire. These registrations were readily converted to stresses by 
means of the cell calibrations, and as such, when projected on a horizontal plane, represented longitudinal sections of the total stress pattern. From the longitudinal sections and the recorded distance that each cell was offset from the center line of the tire, a plan of the dynamic tire-contact patch was drawn and on it a map of equal stress lines was constructed.

\section{Stress-distribution maps}

Figures 7 and 8 show typical stress maps developed from the test data. These maps show measured normal stresses on the projection of the three-dimensional curved interface on a horizontal plane. Since the stress cells are considered to register pressures normal to their surface, the components are obtained by locating the cell positions on the appropriate projection and plotting the accompanying stress magnitude at that point. The maps in Figures 7 and 8 show the distribution of interface stresses beneath the $11.00-20$ tire with a 3000-1b wheel load at an inflation pressure of 15 psi in soft sand and in clay, respectively.

The average cone index in the top 6 in. was greater for the clay. The clay had a cohesive strength of $3.3 \mathrm{psi}$ and its friction angle was 0. The sand at a cone index of 30 had a friction angle of approximately $31 \mathrm{deg}$ and was essentially cohesionless. An effort was made to select a pair of tests in which the maximum "in-soil" deflection was of the same order of magnitude, since this would reflect about equal resistance to displacement and the extent of tire distortion would be about the same in each test. It can be seen that the stresses were most uniformly distributed in the clay, and the high stress zone near the edge of the contact area was not as pronounced as in the sand. The projected contact 
area was smaller for the clay, indicating that average contact pressure was greater.

\section{Resolution of resultant forces}

To resolve the normal stresses acting at the tire-soil interface into a single resultant force, the stresses registered by each cell are first plotted normal to a circumference of the deflected tire--the circumference taken at the same offset from the center line of the cross section of the tire as the cell registering the stresses. Figure 9 is an example of such a plot, showing in this case the circumference of the deflected tire at the center line of the cross section of the tire. The normal stresses registered by a cell at the center line of the tire have been plotted normal to the deflected surface and projected into vertical and horizontal planes. By assuming that the stresses at each point are uniform over some narrow strip whose width is determined by the lateral spacing between the eells, the magnitude and locations of the resultants of the vertical and horizontal components of the normal forces on each strip can be computed. Once this has been done the magnitudes and the locations of the resultant of the horizontal and vertical components of all the measured normal stresses can be determined and these can be resolved into a single resultant if desired, i.e. the resultant of the normal stresses.

The general validity of the stress cell data and of this approach can be demonstrated to a certain degree for towed tests by comparing the measured horizontal and vertical forces to the computed values. This comparison is good, as shown in the following tabulation: 
Comparison of Computed and Measured Forces

\begin{tabular}{|c|c|c|c|c|c|}
\hline \multirow{2}{*}{$\begin{array}{l}\text { Average } \\
0 \text { - to } 6 \text {-in. } \\
\text { Cone Index }\end{array}$} & \multirow{2}{*}{$\begin{array}{c}\text { Inflation } \\
\text { Pressure } \\
\text { psi } \\
\end{array}$} & \multirow{2}{*}{$\begin{array}{l}\text { Applied } \\
\text { Wheel } \\
\text { Load, Ib }\end{array}$} & \multirow{2}{*}{$\begin{array}{l}\text { Measured } \\
\text { Towing } \\
\text { Force, 1b } \\
\end{array}$} & \multicolumn{2}{|c|}{ Computed } \\
\hline & & & & $\begin{array}{l}\text { Wheel } \\
\text { Load, Ib }\end{array}$ & $\begin{array}{l}\text { Towing } \\
\text { Force, }\end{array}$ \\
\hline \multicolumn{6}{|c|}{ Sand } \\
\hline $\begin{array}{l}16 \\
15\end{array}$ & $\begin{array}{l}15 \\
30\end{array}$ & $\begin{array}{l}3000 \\
3000\end{array}$ & $\begin{array}{r}870 \\
1028\end{array}$ & $\begin{array}{l}2950 \\
2961\end{array}$ & $\begin{array}{r}862 \\
1098\end{array}$ \\
\hline 16 & 60 & 3000 & 1115 & 2914 & 1142 \\
\hline $\begin{array}{l}24 \\
30\end{array}$ & $\begin{array}{l}15 \\
15\end{array}$ & $\begin{array}{l}3000 \\
3000\end{array}$ & $\begin{array}{l}760 \\
609\end{array}$ & $\begin{array}{l}3230 \\
3104\end{array}$ & $\begin{array}{l}703 \\
563\end{array}$ \\
\hline $\begin{array}{l}27 \\
57 \\
54\end{array}$ & $\begin{array}{l}60 \\
15 \\
60\end{array}$ & $\begin{array}{l}3000 \\
3000 \\
3000\end{array}$ & $\begin{array}{r}1000 \\
166 \\
943\end{array}$ & $\begin{array}{l}3032 \\
3130 \\
3147\end{array}$ & $\begin{array}{r}1124 \\
187 \\
1083\end{array}$ \\
\hline
\end{tabular}

$\underline{\text { Clay }}$

$\begin{array}{rrrrrr}41 & 15 & 3000 & 405 & 3028 & 412 \\ 47 & 30 & 3000 & 712 & 3260 & 765 \\ 45 & 60 & 3000 & 755 & 3323 & 797 \\ 28 & 15 & 3000 & 1020 & 2990 & 1220 \\ 29 & 30 & 3000 & 1135 & 2986 & 1365 \\ 28 & 60 & 3000 & 1180 & 2980 & 1208\end{array}$

The computation using the data gathered in this program indicates that the resultant of all the normal stresses at the tire-soil interface appears to intersect the center of the axle for both towed and powered tests. Of 25 towed tests and 7 powered tests analyzed, the resultant normal force always passed within $0.5 \mathrm{in}$. of the axle center line. In only six instances was the distance (a, Figure 9) more than 0.2 in. In all where did not intersect the center of the axle, it cases / the resultant, $\mathrm{F}_{r}$ / passed forward of the center line of the axle.

If the resultant of the normal force passes through the axle, it creates no moment about the axle. This suggests that the resultant of the tangential stress must be zero, or very nearly so, for a towed test. However, negative slip is known to occur in a towed test (i.e. the wheel skids 
slightly), and slip must be accompanied by some tangential forces. Therefore, a tangential force acting in the direction opposite to the slipinduced force must be set up at the interface. Apparently this counterbalancing force is produced by the formation of a bow wave of soil in front of the wheel. By the same token it appears that in powered-wheel tests the resultant of the tangential stresses is directly related to the torque input and the deflected radius of the tire.

\section{Stress patterns}

To give some indication of the distribution of stresses at the tiresoil interface without showing complete stress maps, the stresses measured by a cell at the center line of the tire's cross section and a cell at an offset of $3.75 \mathrm{in.}$ are shown in Figures 10 through 15 . The drawings of the deflected tire and the location of the soil surfaces shown in these figures refer only to the center line of the tire.

\section{Results of Tests in Sand}

\section{Towed tire}

Analysis of the results of the towed tire tests in sand indicated that the general shape of the stress patterns tends to be different for each of the three different tire deflections studied. The drawings in Figure 10 are intended to illustrate the three different general types of stress-distribution patterns that could be distinguished in these tests.

The stress patterns shown in plot a of Figure 10 are typical of those from tests in which the in-soil tire deflection was small, usually less than 10 percent. These patterns are identified by the single-peaked curves, both at the center line and at the offset. Tests in which the 
in-soil tire deflection was greater than about 20 percent usually produced curves of the type shown in plot c of Figure 10. For these tests, the center-line cell always exhibited two maxima in the stress wave, and the cell at the 3.75-in. offset produced single-peaked stress waves. The third pattern, shown in plot $\mathrm{b}$ of Figure 10, represents the intermediate case between the two just described. The tire deflection usually is between about 10 and 20 percent. The center-line cells and the offset cells tend to show a relatively constant stress for a significant portion of the stress wave; and if the curves produced by all cells are averaged, the average stress at any cross section is about the same for the major portion of the contact length.

Towed- versus powered-wheel tests

Figures 11 and 12 display comparisons of results of towed- and powered-wheel tests in sand showing the distribution of stresses on the horizontal and vertical projections of the contact areas. The wheel load was $3000 \mathrm{lb}$, and inflation pressures were adjusted to produce hard-surface deflections (percent reduction in carcass section height) of 15 and 25 percent, respectively.

In both figures certain observations can be made. The towed wheel produced a deeper rut than the powered wheel under similar conditions of load, deflection, and soil. Stresses produced by the bow wave were greater during the powered tests, and although the exact positions are not shown, it is apparent that the centroid of the vertical component of the normal stresses was a greater distance forward of the axle during the powered tests. Although the stress patterns are somewhat different, the general appearance is the same for towed and powered tests at similar conditions 
and the peak stress values are of the same order of magnitude. In each pair of tests, the maximum center-line deflection is slightly greater for the towed tire.

\section{Results of Towed-Wheel Tests in Clay}

Results of tests at a wheel load of $3000 \mathrm{lb}$ and inflation pressures of 60 and $15 \mathrm{psi}$ are represented in Figure 13. This figure shows the distribution of stresses on the horizontal and vertical projections of the contact area. This particular pair of tests was chosen to illustrate the fact that the stresses remain uniformly distributed for a wide range of deflections. Maximum center-line deflection during the 60-psi test was approximately 3.5percent, and during the 15-psi test it was approximately 18 percent. The stresses in the center portion of the contact area were higher than those at the offset position during the 60-psi test; the reverse was true during the 15-psi test. Apparently, in this soft, cohesive material a plastic flow condition develops in the soil beneath the tire and thus reduces the possibility that zones of higher stresses may develop at the tire-soil interface as they do during tests in sand.

\section{A Comparison of Towed Tests in Sand and Clay}

In Figures 14 and 15, the distribution of the components of the normal stresses on the horizontal and vertical projections of the contact areas is shown. The wheel load was $3000 \mathrm{lb}$ and the inflation pressures were 60 and $15 \mathrm{psi}$, respectively. To make this comparison, pairs of tests were chosen in which the maximum in-soil deflection was of the same order of magnitude. As previously mentioned, this indicates that the total 
resistance to displacement and the extent of the tire distortion were about the same in both the sand and the clay tests.

In both figures the following points are obvious: (a) The interface stresses are more evenly distributed during the tests in clay, and the peak stress values recorded are slightly less than those recorded for the tests in sand. (b) At the front of the contact areas, the stresses increase in magnitude at a faster rate during the clay tests, probably because the bow wave in a cohesive material remains an integral part of the soil mass, having about the same cohesive strength as the mass itself, even though it is being deformed, whereas the bow wave in sand is a disturbed material in a very loose condition. (c) The contact lengths and sinkages are larger for the tests conducted in sand when the maximum deflection of the tire in sand and in clay is of the same order of magnitude.

The position of the lowest point on the deflected tire is indicated in Figures 14 and 15. It is seen that rebound of the clay soil produces normal stresses to the rear of the lowest point on the deflected circumference, which always fell at, or beyond, a point directly beneath the axle. The approximate amount of rebound estimated from the tire-deflection plot for the two tests shown is 0.2 in.

\section{Conclusions}

On the basis of the data presented in this paper, it is concluded that:

a. The line of the resultant of the normal stresses at the tire-soil interface passes through the center line of the wheel axle for towed and powered wheels. 
b. In sand, the shape of the stress-distribution pattern is related to the magnitude of the maximum in-soil deflection of the moving tire as measured at the center line of the tire cross section.

c. Interface stresses are more evenly distributed when the tire is operating in a soft clay soil than when it is operating in ... sand, i.e. zone of higher stresses is not as pronounced and the peak stress values reached are slightly less than those recorded during a sand test. 


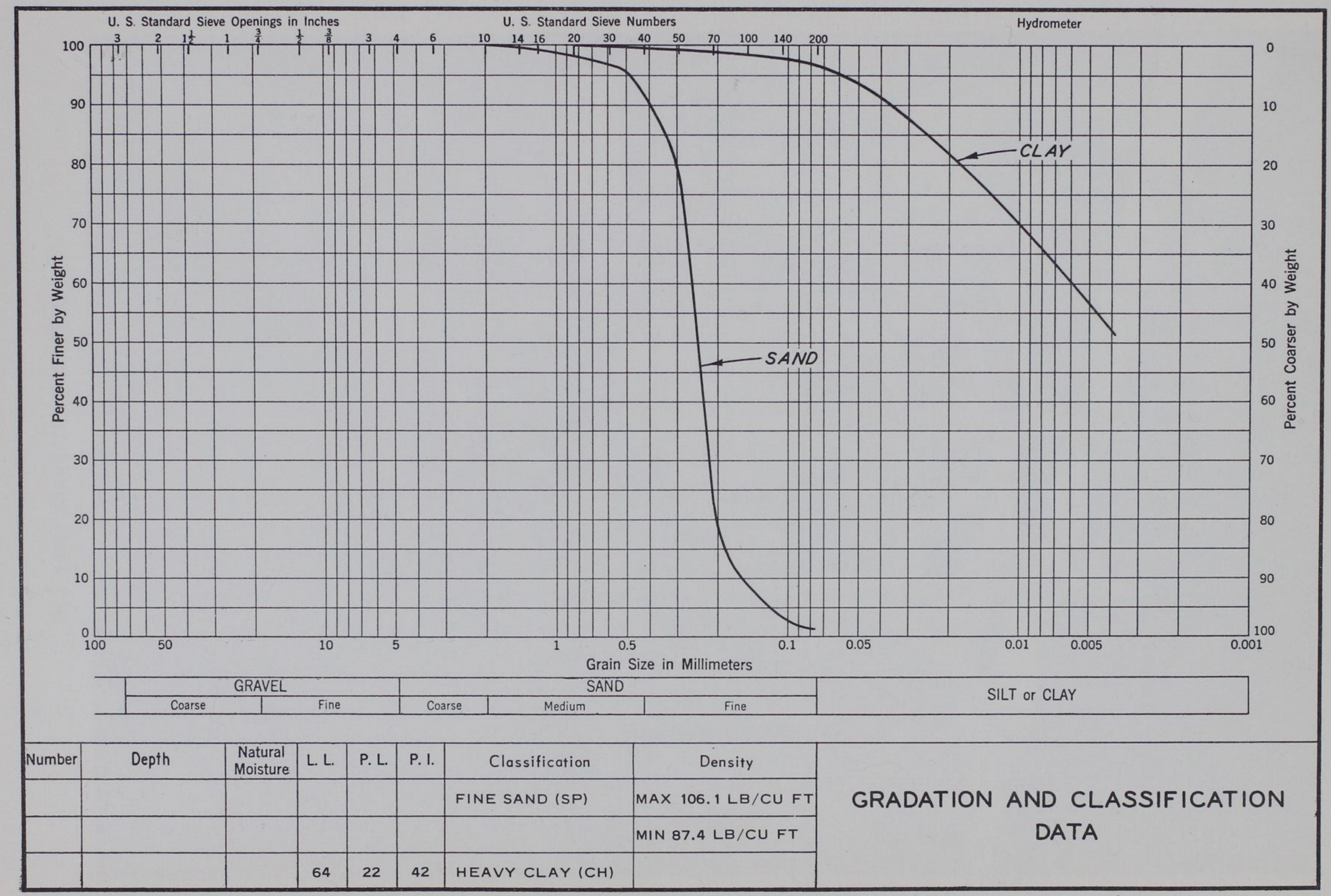




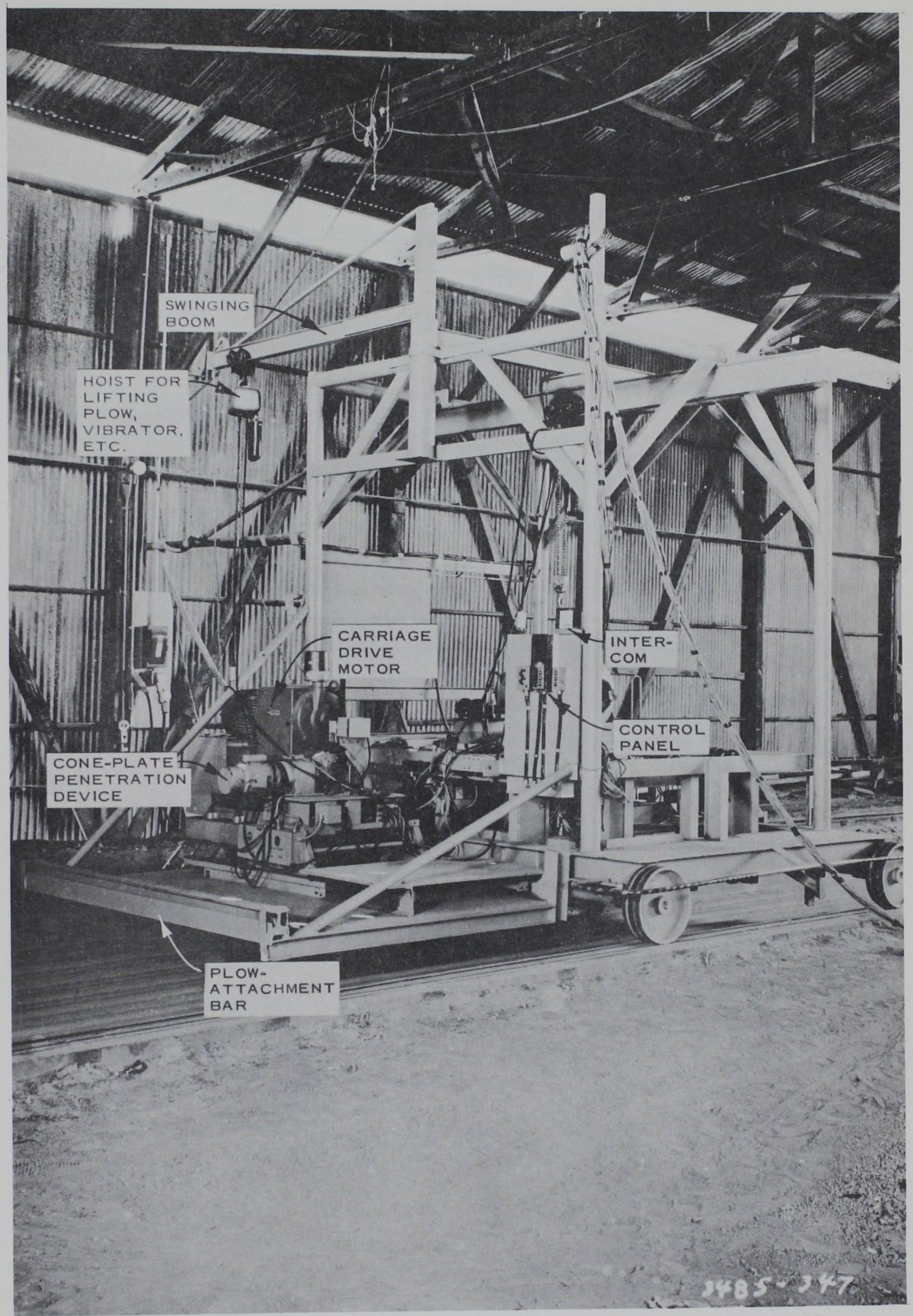

Rear view of large test rig 

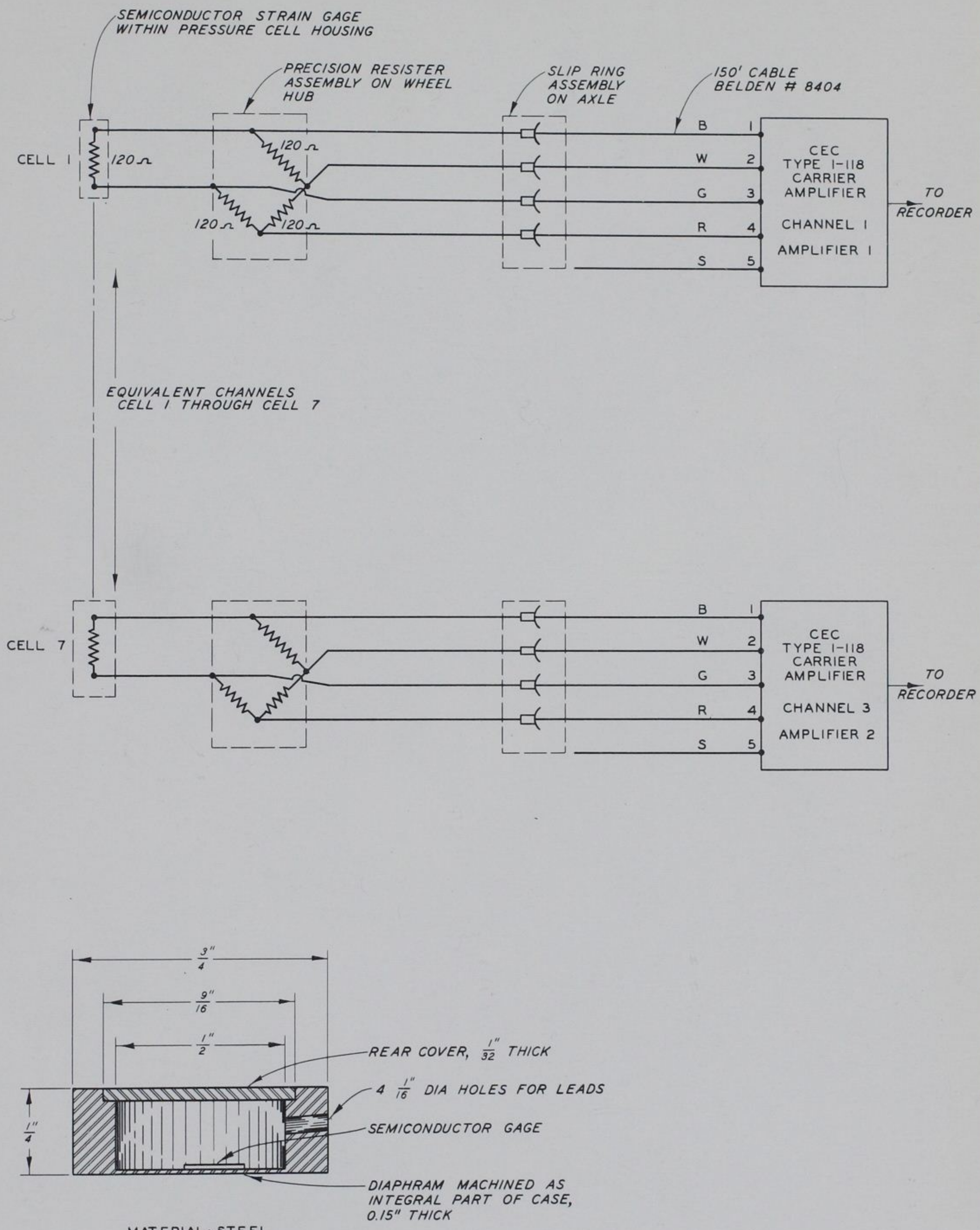

MATERIAL: STEEL

$0.15^{\prime \prime}$ THICK

SECTION

ELECTRICAL SCHEMATIC DRAWING OF WES PRESSURE CELL AND AMPLIFIER 


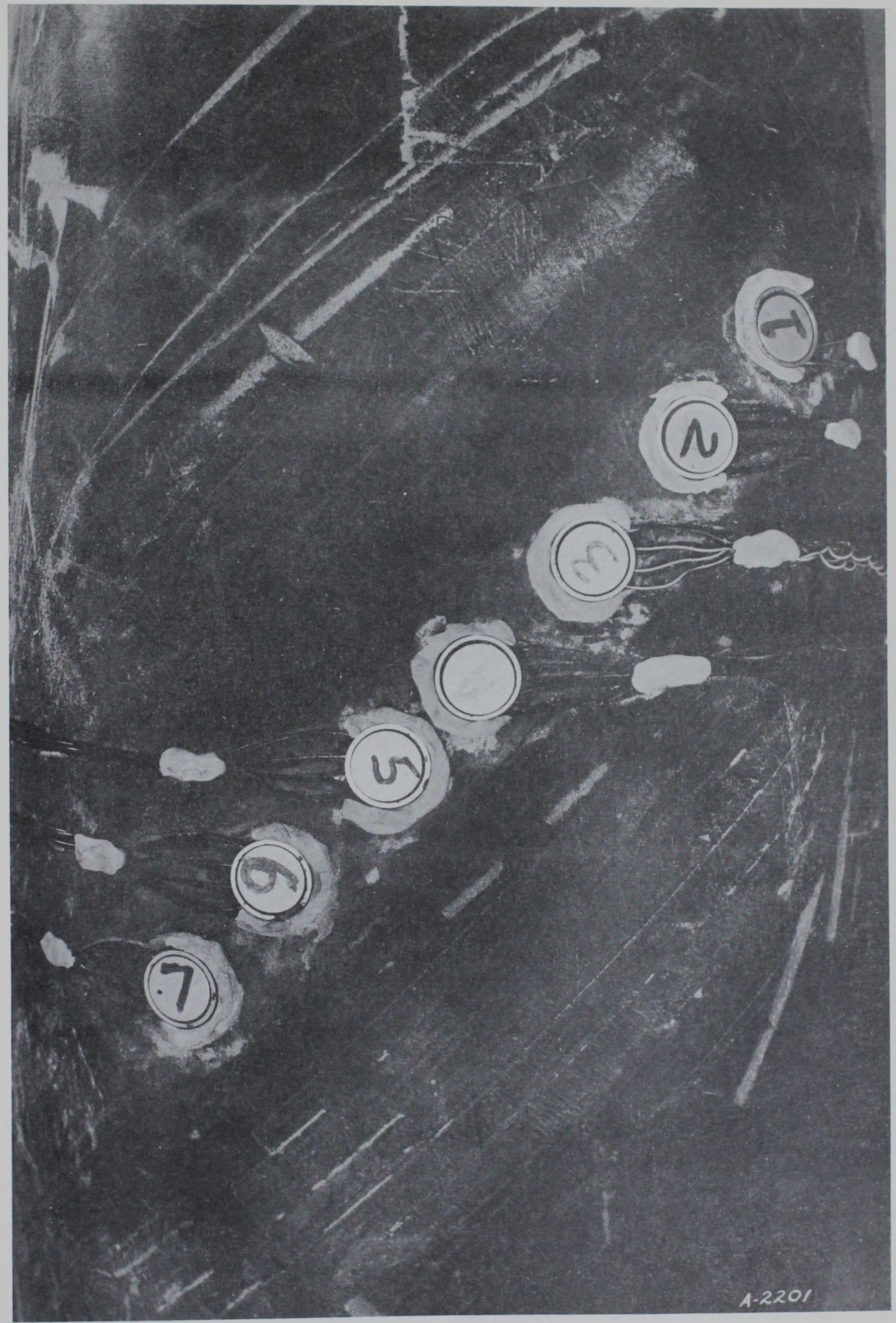




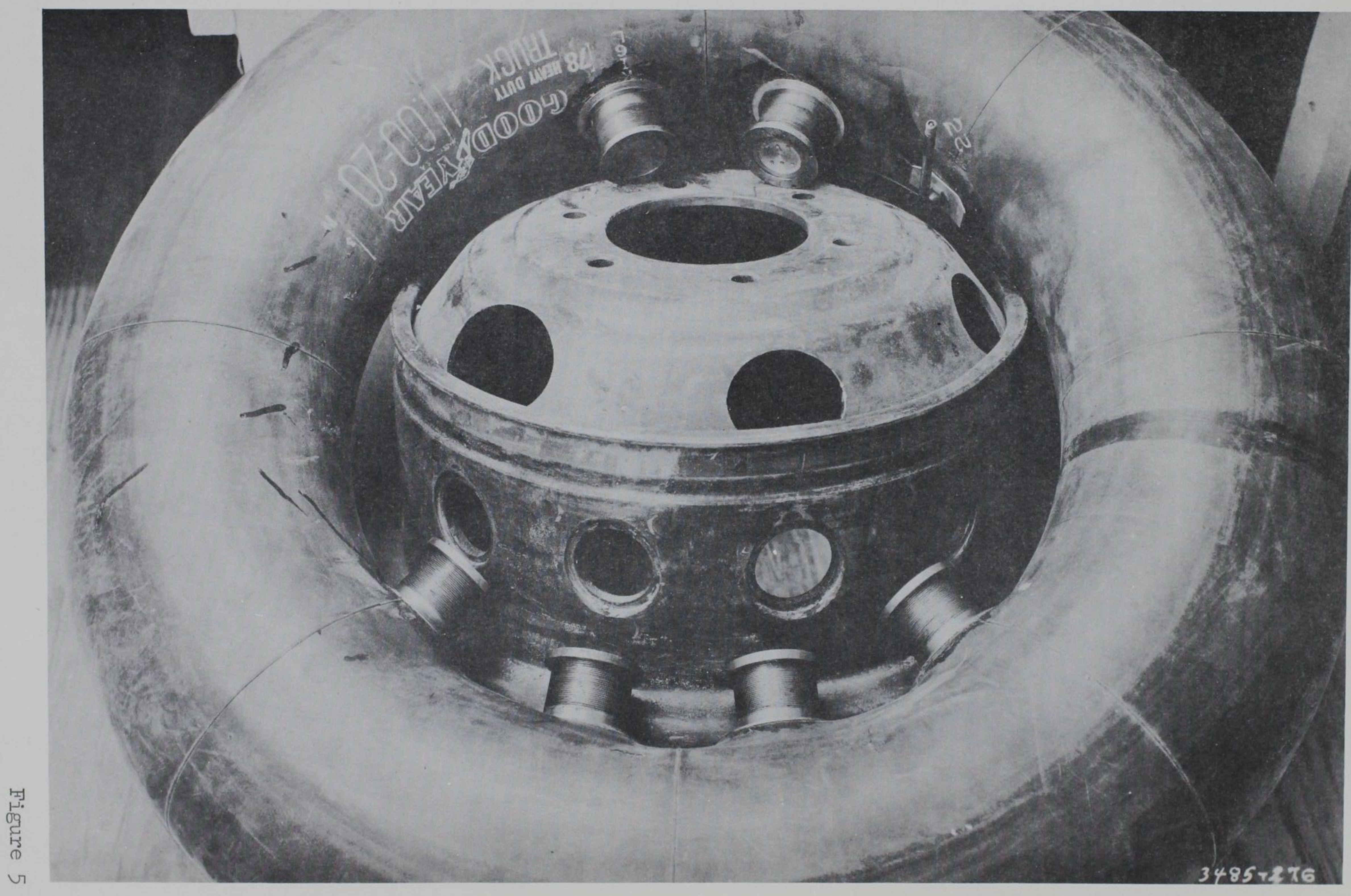




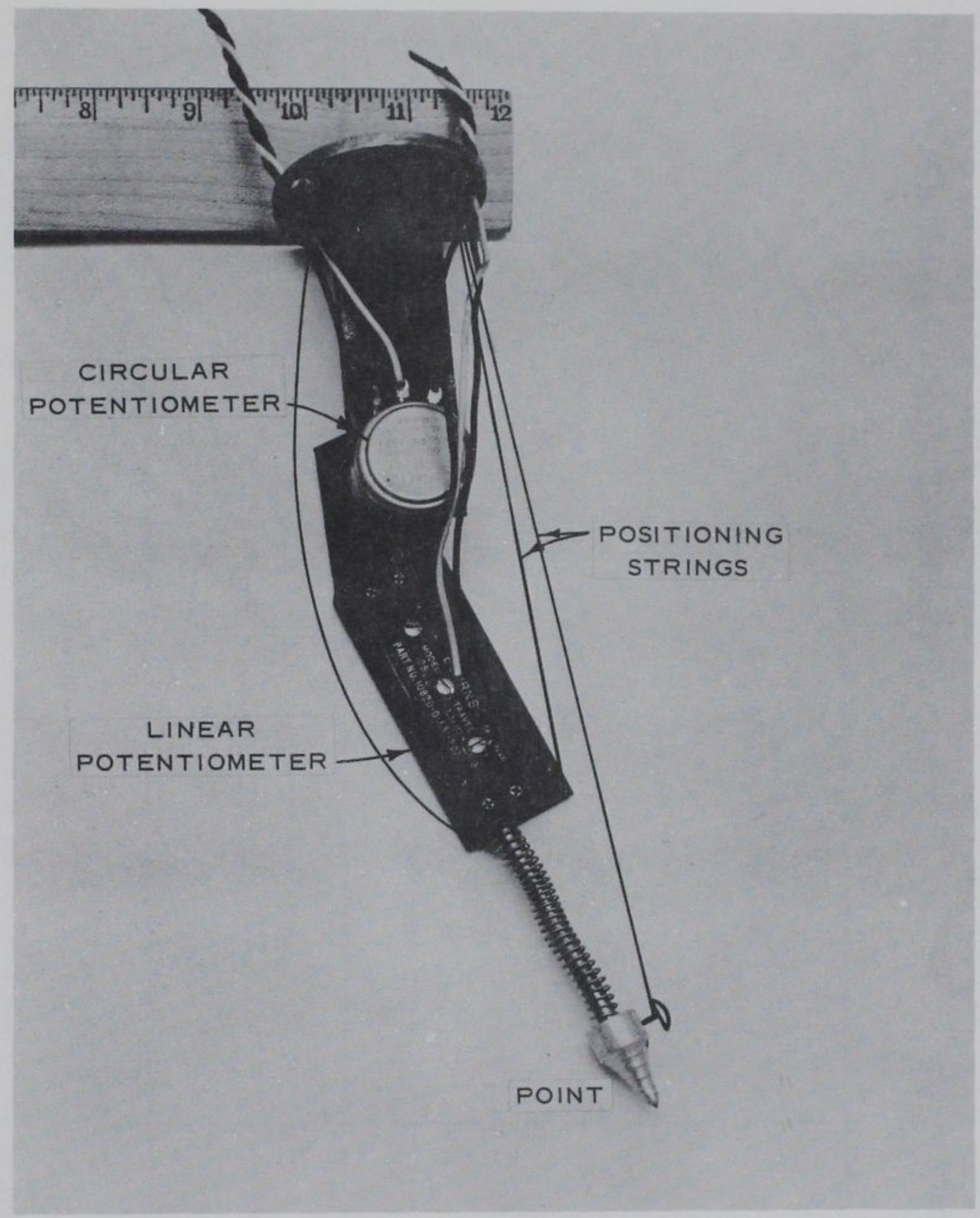

Deflection gage

Figure 6 


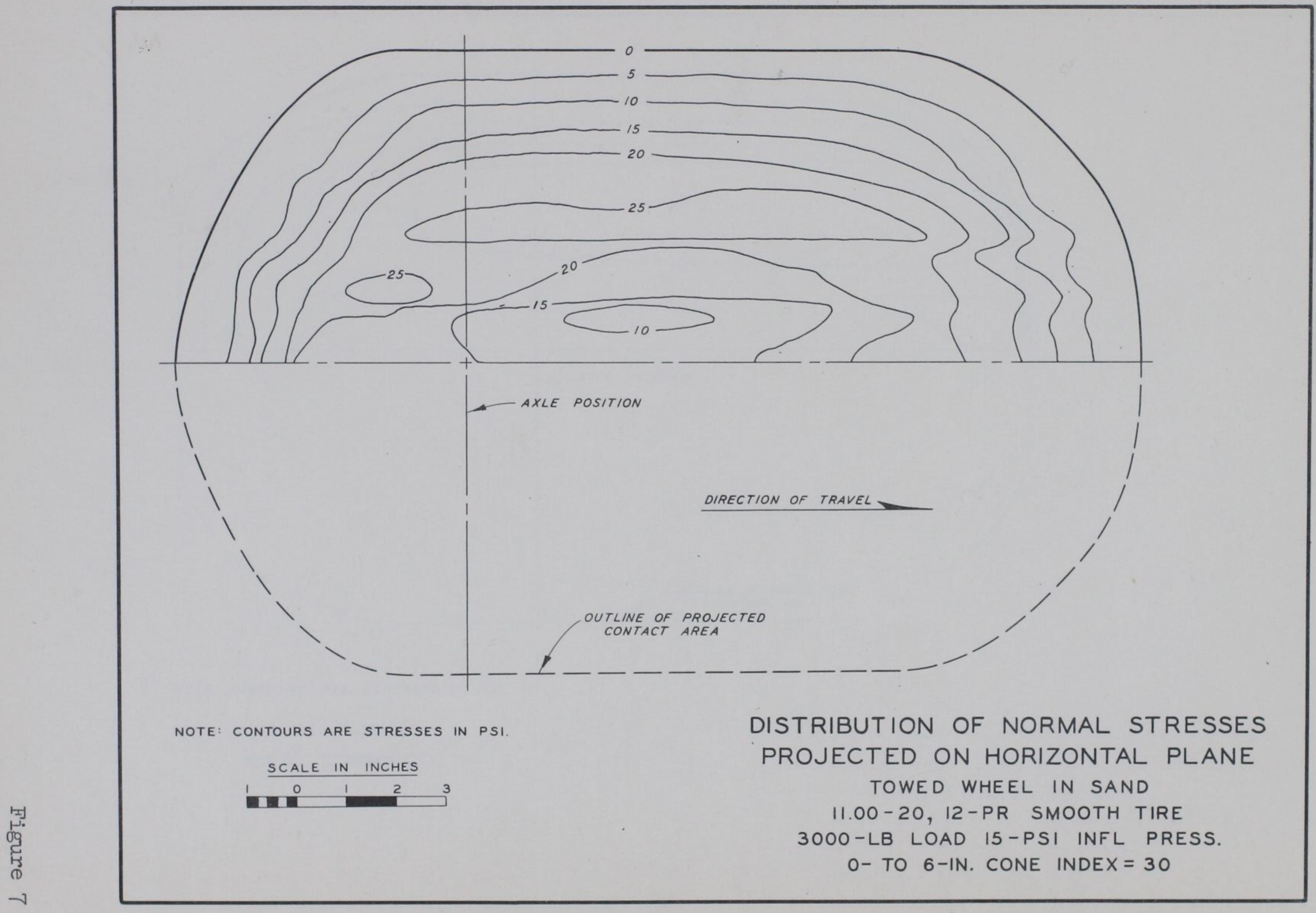




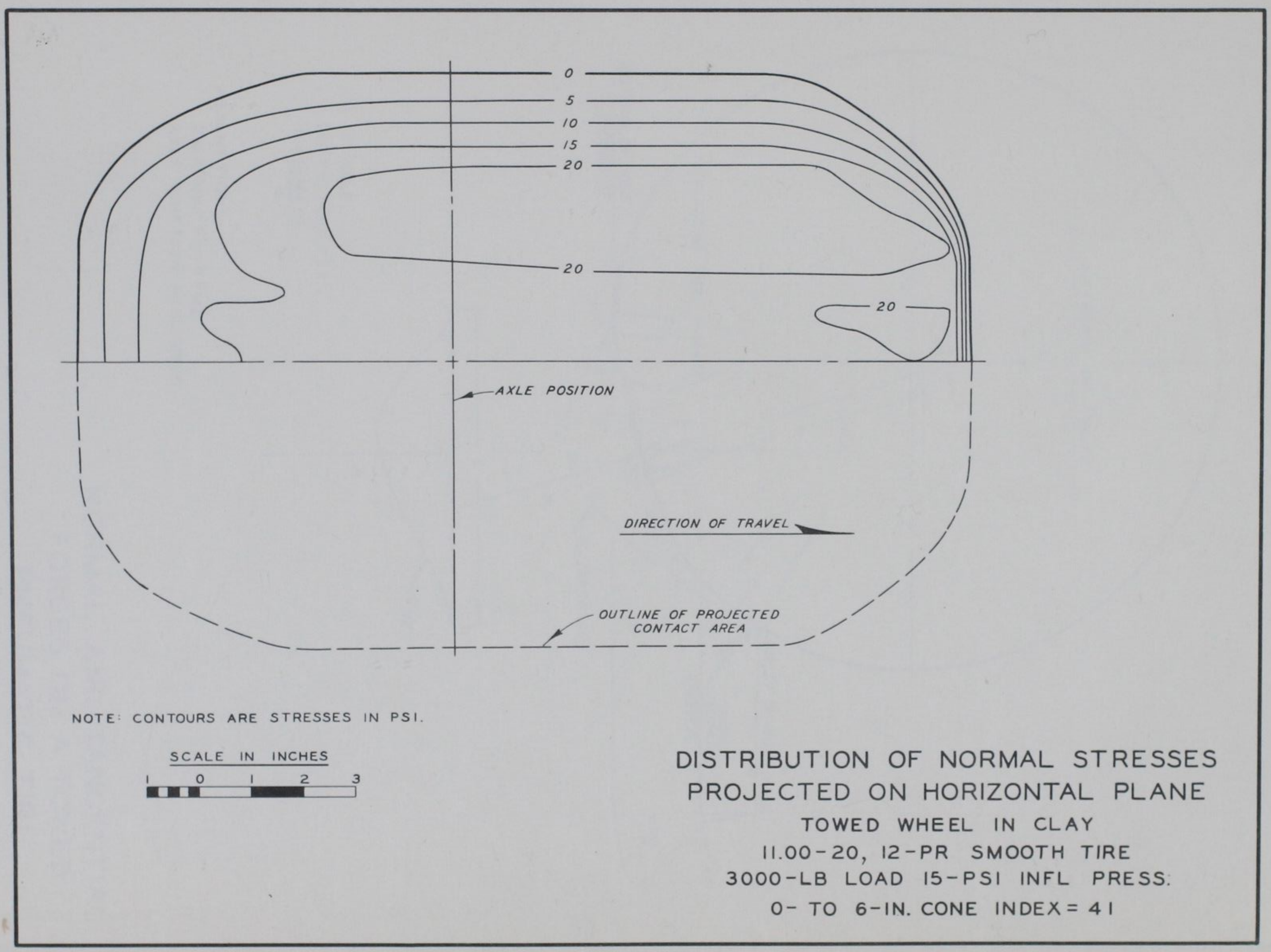




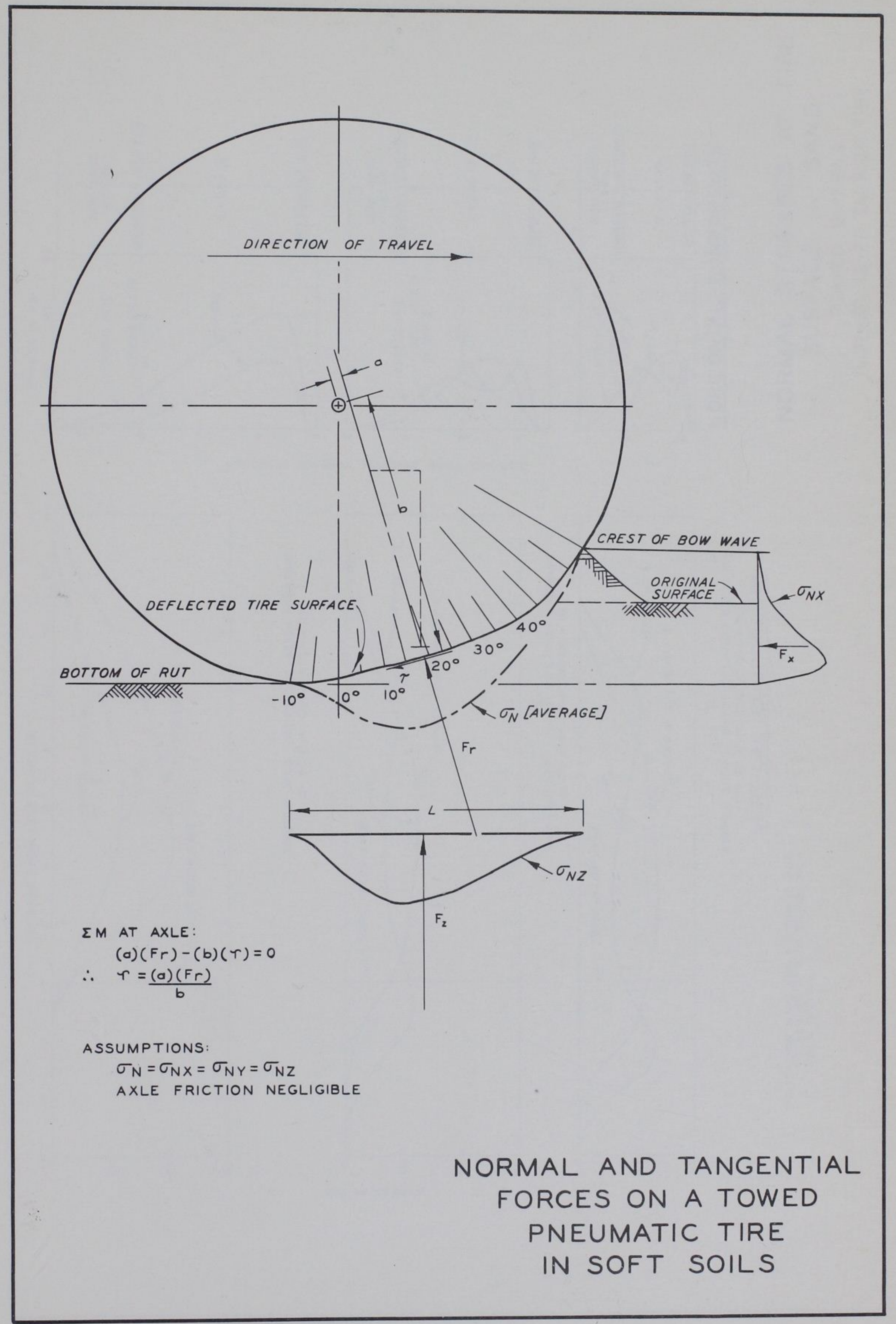

\section{5}




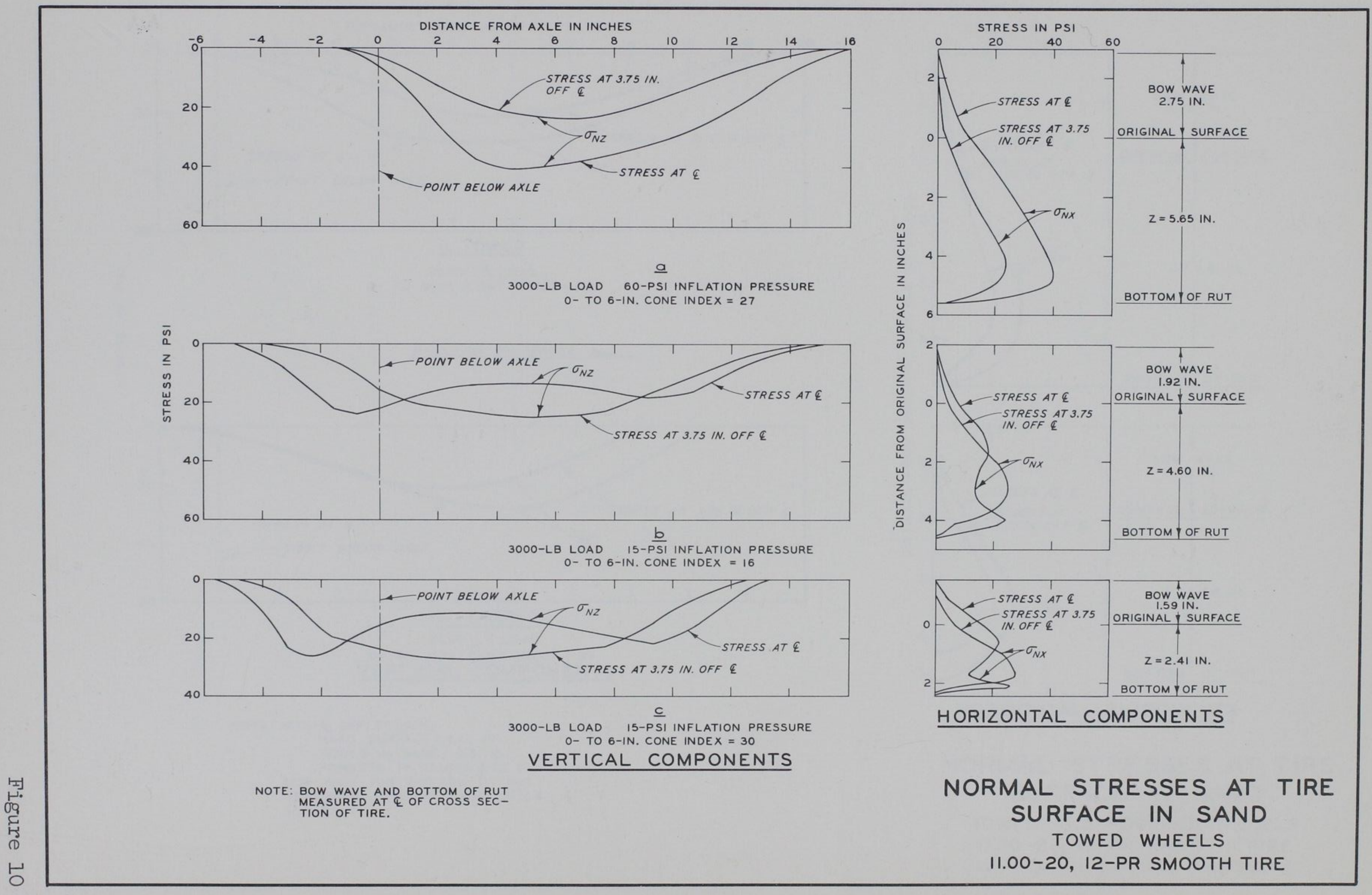




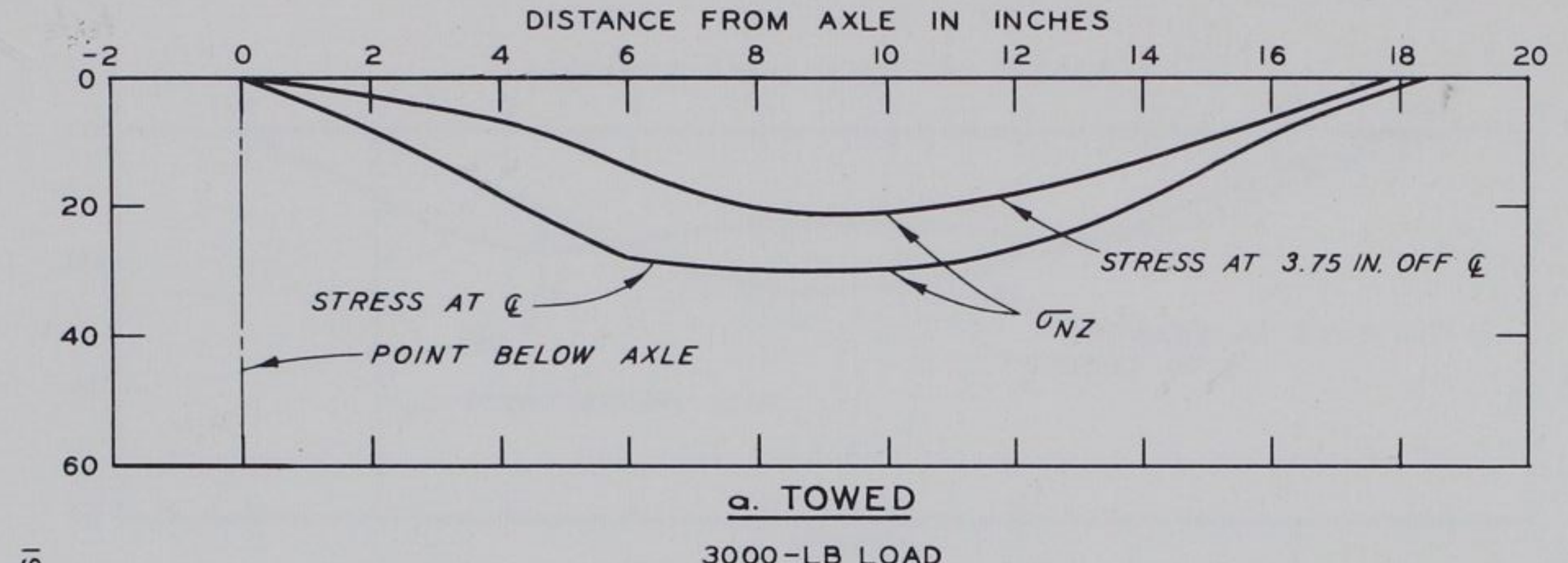

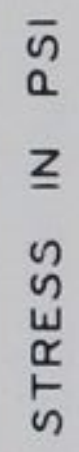

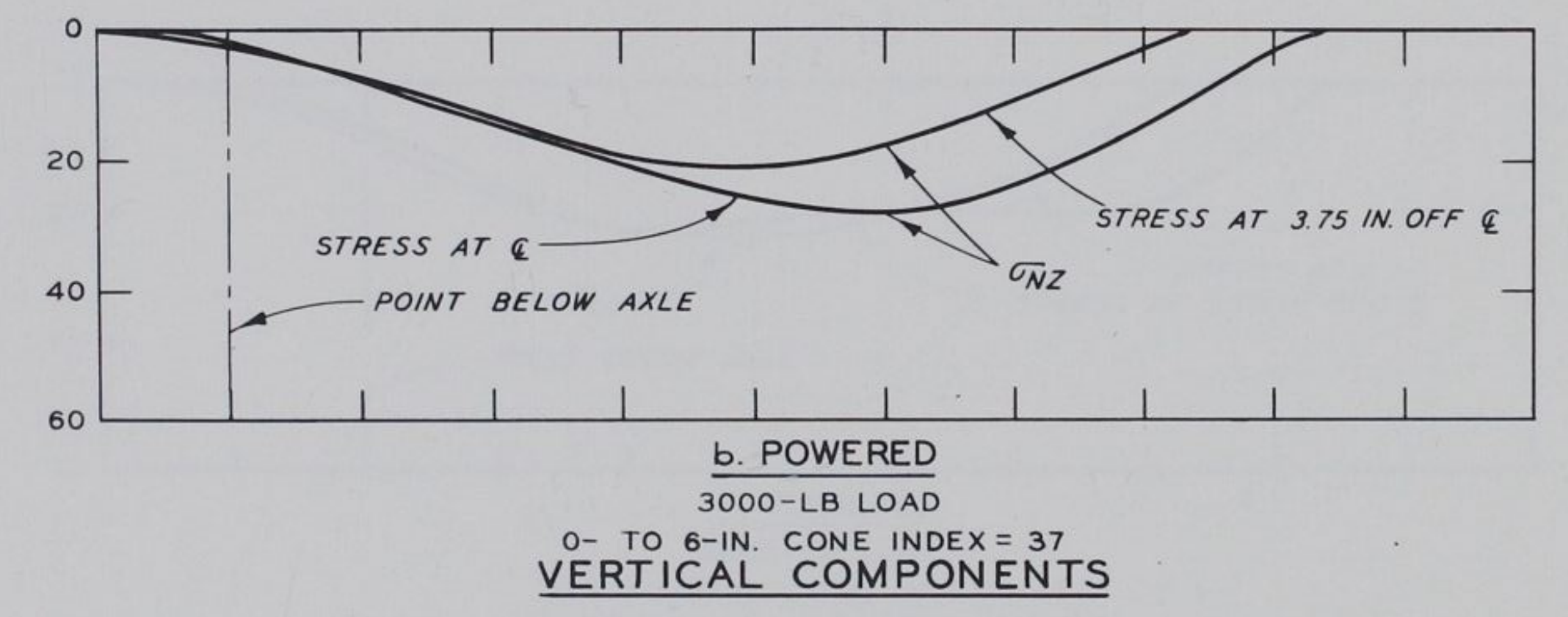

NOTE: MAX \& DEFLECTION;

HARD SURFACE $\approx 1.12 \mathrm{IN}$

TOWED IN SAND $=0.51$ IN

POWERED IN SAND $=0.42 \mathrm{IN}$

BOW WAVE AND BOTTOM OF RUT

MEASURED AT \& OF TIRES CROSS SECTION

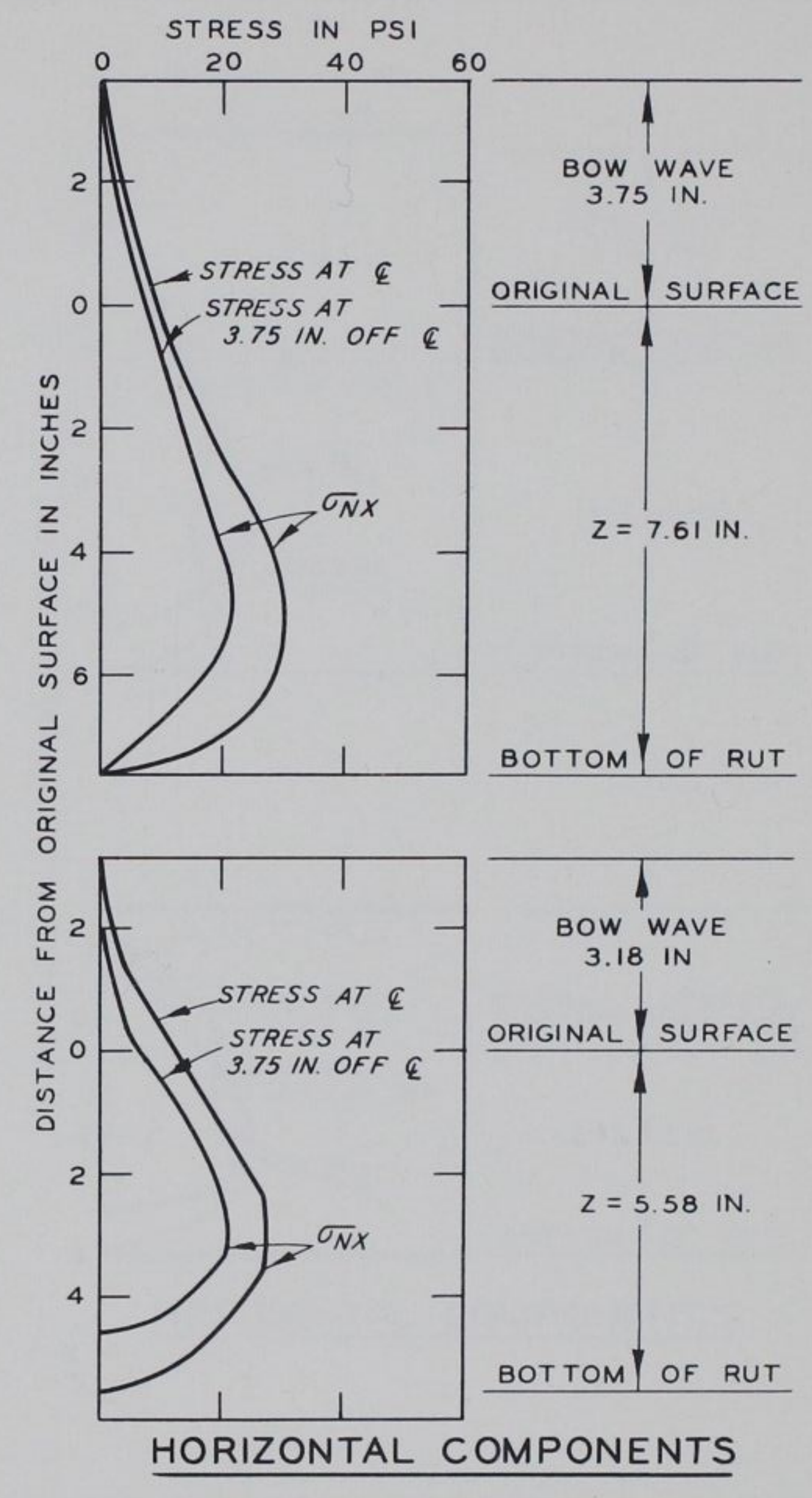

NORMAL STRESSES AT TIRE SURFACE IN SAND

TOWED AND POWERED WHEELS II.00-20, I2-PR SMOOTH TIRE 46-PSI INFLATION PRESSURE 

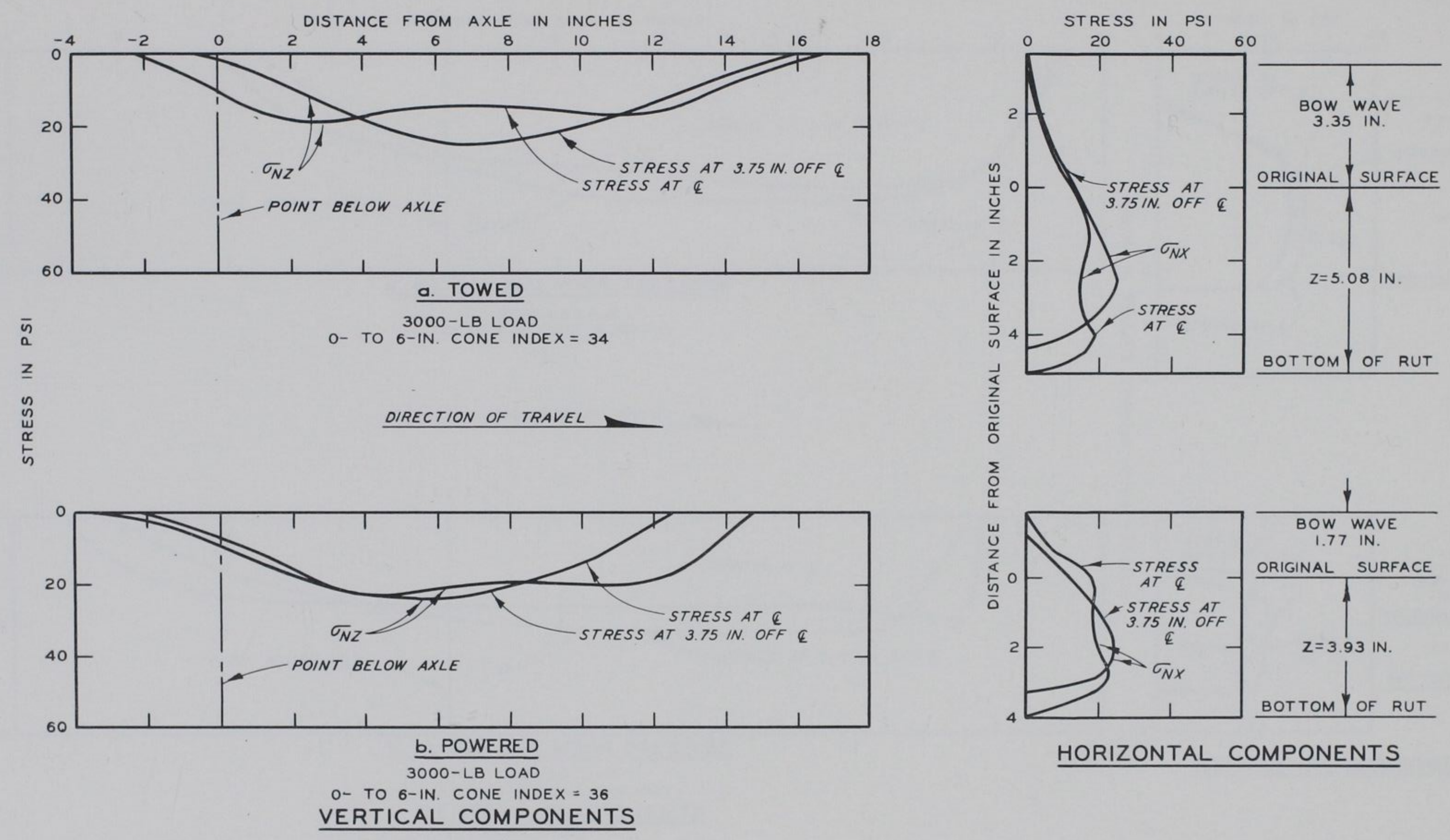

HORIZONTAL COMPONENTS

NOTE: MAX \& DEFLECTION:

HARD SURFACE $\approx 2.1$ IN.

TOWED IN SAND $=1.48$ IN.

POWERED IN SAND $=1.42$ IN

MEASURED AT E OF TIRES CROSS

SECTION.

NORMAL STRESSES AT TIRE SURFACE IN SAND

TOWED AND POWERED WHEELS 11.00-20, I2-PR SMOOTH TIRE

19-PSI INFLATION PRESSURE 


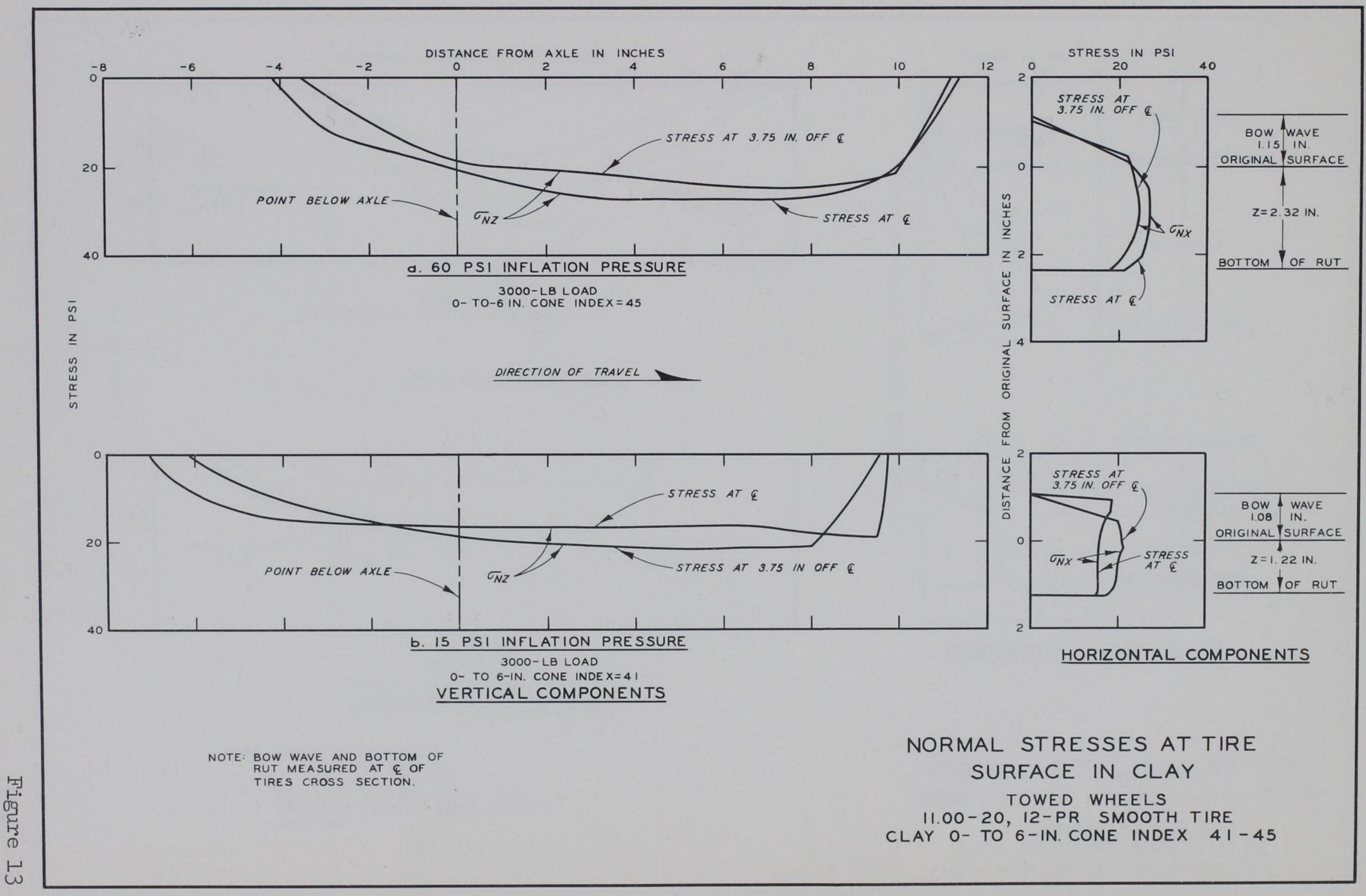




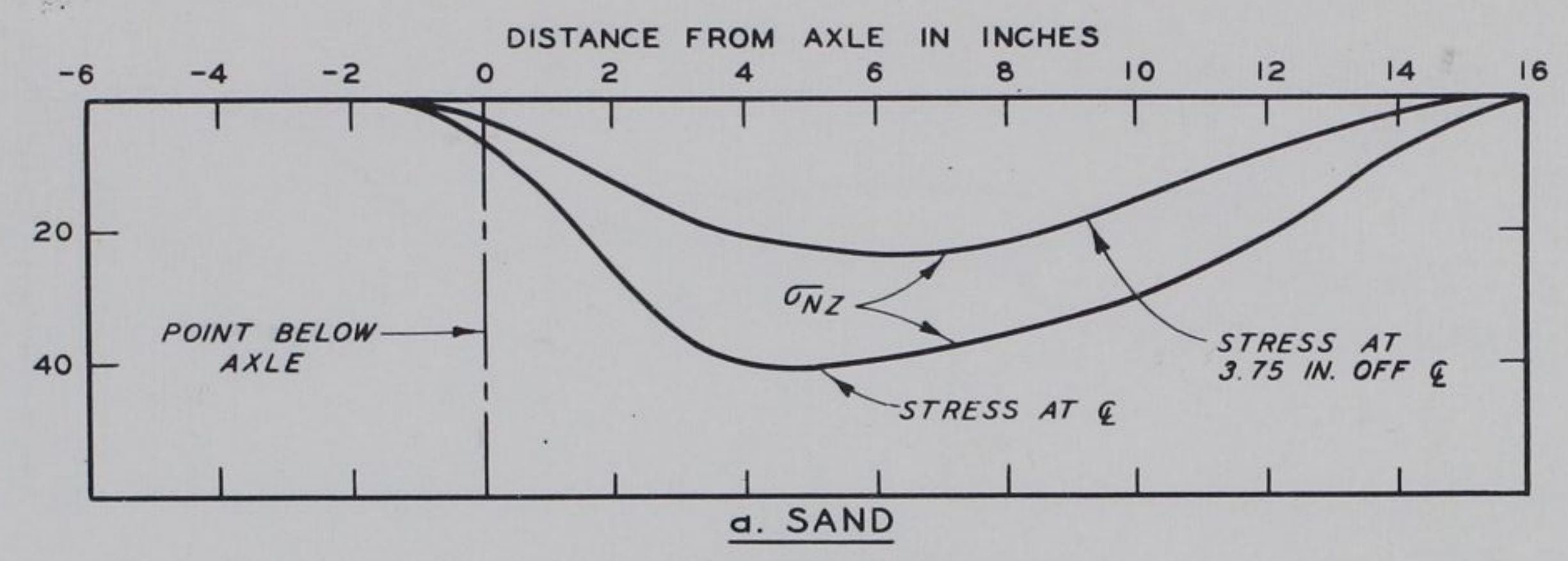

$\bar{n}$
$a$
$z$
$n$
$n$
$w$
$\alpha$
5
$n$

$3000-$ LB LOAD
SAND $0-$ TO 6 IN. CONE INDEX $=27$

DIRECTION OF TRAVEL

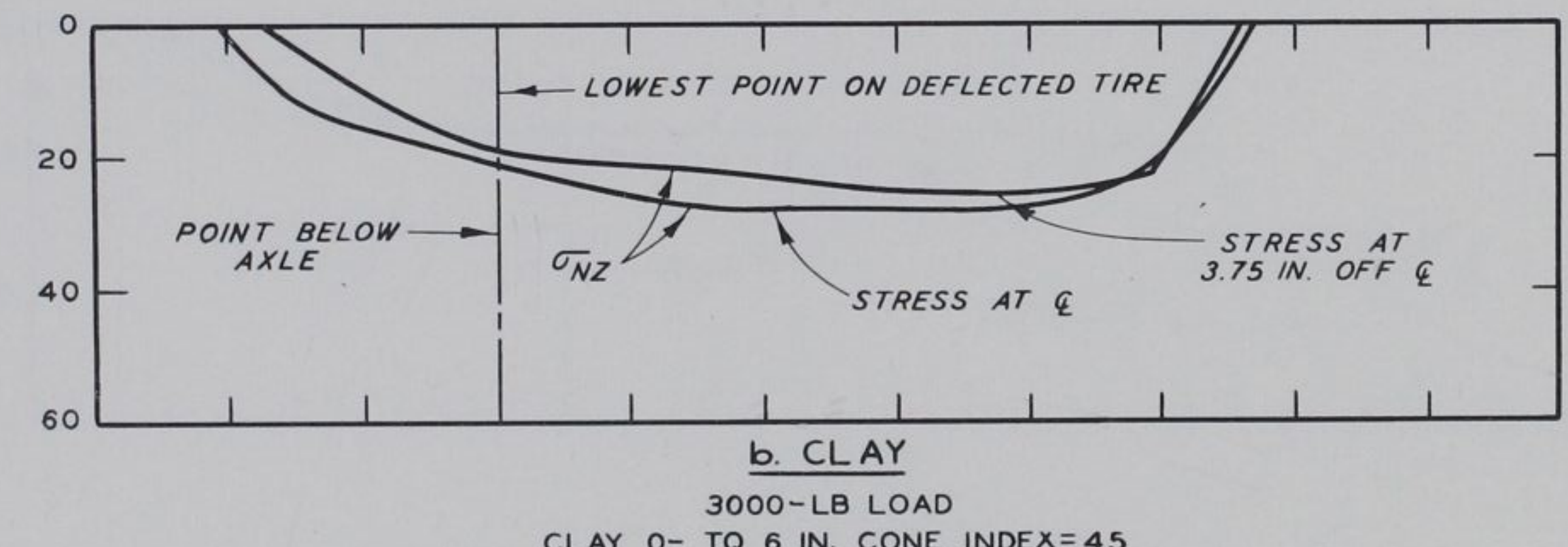

CLAY O- TO 6 IN. CONE INDEX 45

NOTE: MAX \& DEFLECTION;

IN SAND $=0.45 \mathrm{IN}$

BOW WAVE AND BOTTOM OF RUT

MEASURED AT \& OF TIRES CROSS

SECTION.

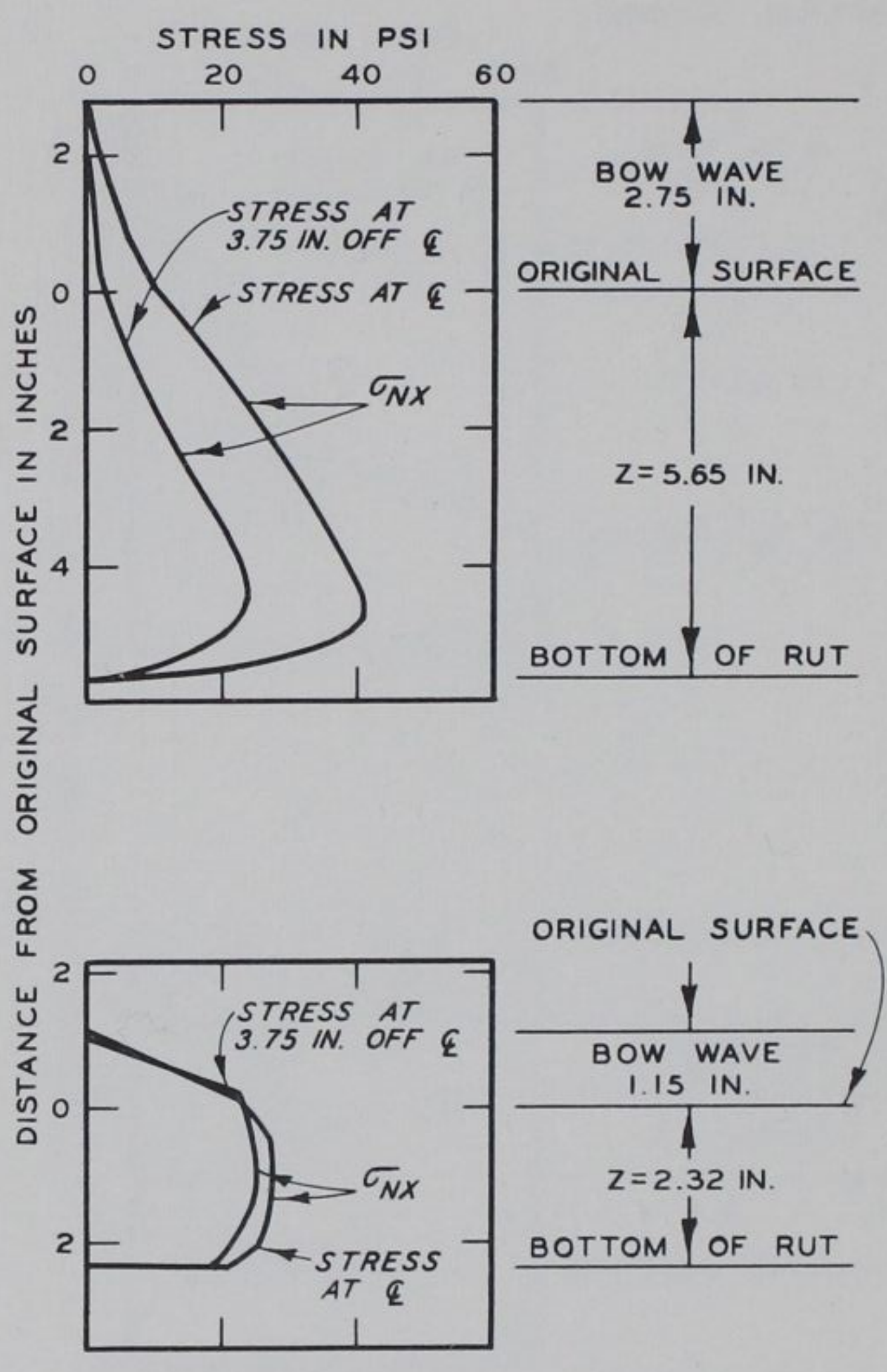

HORIZONTAL COMPONENTS

NORMAL STRESSES AT TIRE SURFACE IN SAND AND CLAY TOWED WHEELS 11.00-20, I2-PR SMOOTH TIRE 60-PSI INFLATION PRESSURE 

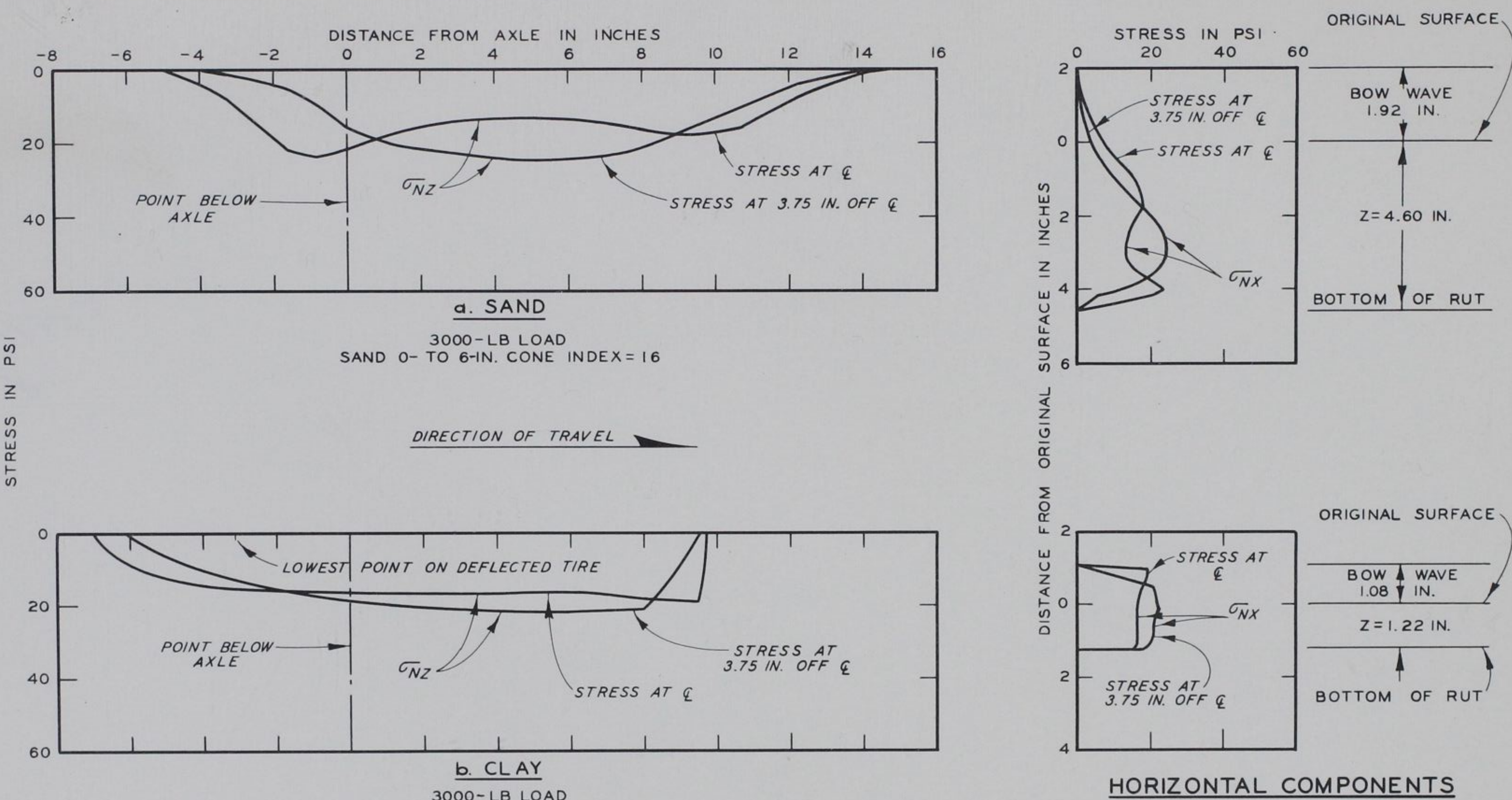

CLAY O- TO 6-IN. CONE INDEX $=4$ I

VERTICAL COMPONENTS

NOTE: MAX \& DEFLECTION:

IN SAND $=1.80 \mathrm{IN}$

IN CLAY $=1.62 \mathrm{IN}$

DIRECTION OF TRAVEL

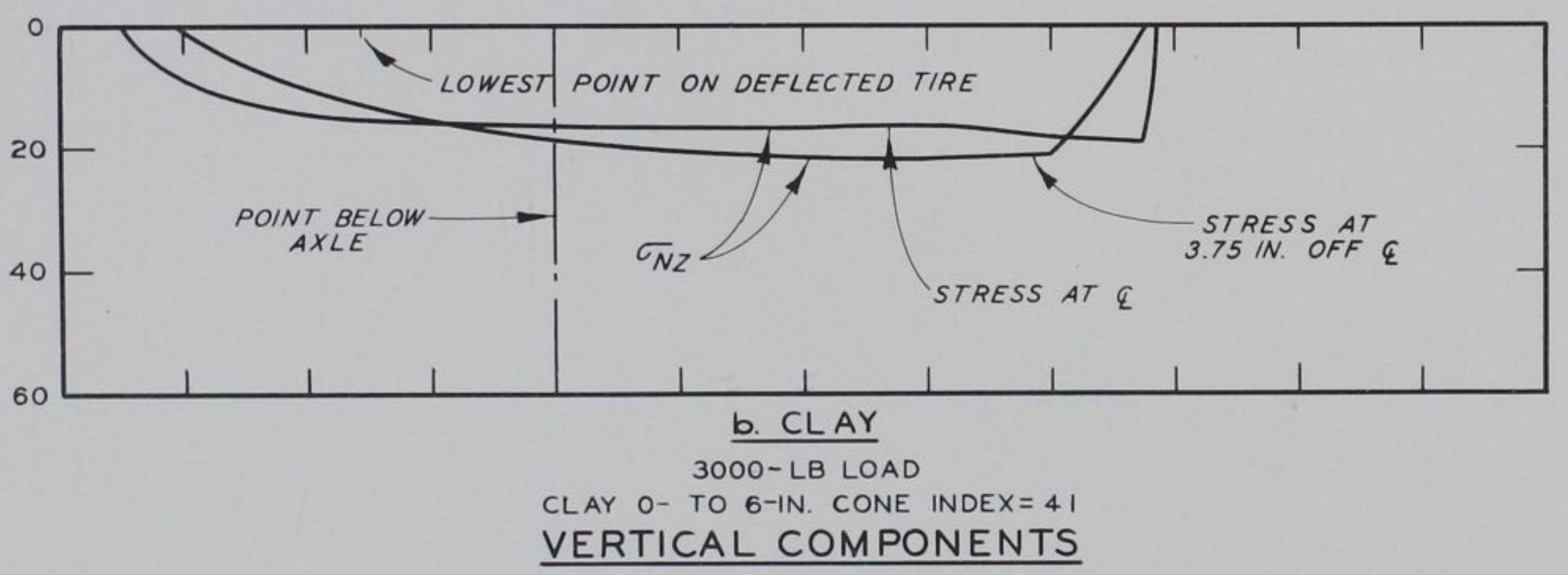

AT \& OF TIRES CROSS

SECTION

NORMAL STRESSES AT TIRE SURFACE IN SAND AND CLAY TOWED WHEELS 